University of Nebraska - Lincoln

DigitalCommons@University of Nebraska - Lincoln

$12-1968$

\title{
Some Observations on Maccoa Duck Behaviour
}

Paul A. Johnsgard

University of Nebraska-Lincoln, pajohnsgard@gmail.com

Follow this and additional works at: https://digitalcommons.unl.edu/johnsgard

Part of the Ornithology Commons

Johnsgard, Paul A., "Some Observations on Maccoa Duck Behaviour" (1968). Paul Johnsgard Collection. 15.

https://digitalcommons.unl.edu/johnsgard/15

This Article is brought to you for free and open access by the Papers in the Biological Sciences at DigitalCommons@University of Nebraska - Lincoln. It has been accepted for inclusion in Paul Johnsgard Collection by an authorized administrator of DigitalCommons@University of Nebraska - Lincoln. 


\title{
SOME OBSERVATIONS ON MACCOA DUCK BEHAVIOUR
}

\author{
Paul A. Johnsgard \\ Received March 1968
}

The recent comprehensive review of Maccoa Duck Oxyura maccoa biology by Clark (1964) has provided the first detailed summary of the species' reproductive behaviour patterns and other aspects of breeding in this little-studied stiff-tail. It has been evident that the evolutionary relationships of the Maccoa Duck to the other southern hemisphere stiff-tails and the northern species of Oxyura are still uncertain at best, as evidenced by the varied taxonomic treatment that the Maccoa has received from Delacour and Mayr (1945), who regarded it as a race of $O$. australis, from Boetticher (1952), who considered it as a race of $O$. jamaicensis, and from Delacour (1959), who finally concluded that it represents a distinct species. There can be little doubt that the last approach is most realistic, but the question still remains as to which of the other species of Oxyura the Maccoa is most closely related. In 1961 I suggested that the Argentine Ruddy Duck $O$. vittata, the Australian Blue-billed Duck $O$. australis and the Maccoa Duck comprised an evolutionary group distinct from the other forms of Oxyura. Additional evidence supporting this view has since been summarized (Johnsgard 1967), when a comparison of male display patterns of the stiff-tails was undertaken. This survey was an admittedly preliminary one, since the author had never had an opportunity to study the displays of certain stiff-tails, including the Maccoa, and published descriptions were necessarily relied upon. Recently, unpublished notes, cine films, and other information on the Maccoa had been made available, and it has become increasingly apparent that the Maccoa is a species of unusual interest.

As pointed out in the recent survey, male display patterns of the Oxyura species studied so far seem to fall into two general patterns. One is represented by the North American Ruddy Duck $O$. jamaicensis and the European White-backed Duck $O$. leucocephala, both of which utilize a display sequence called Bubbling (Johnsgard 1965) as their primary male courtship ritual, and which involves a rapidly repeated tapping of the tracheal air sac with the mandible, followed by a weak belching note uttered with the neck stretched forward. The Australian Blue-billed Duck and the Argentine Ruddy Duck, however, evidently lack Bubbling altogether, and the primary male courtship display of at least the former species consists of a remarkable series of splashing movements called Sousing (Johnsgard 1966). The Argentine Ruddy Duck is also known to possess this display and film sequences taken by Dr Jack Bradbury indicate that it is extremely similar in form to that of the Australian species. Likewise, Clark (1964:266) described a Maccoa display identifiable as Sousing which usually occurs in males when in the presence of a female, but also occasionally when disturbed by humans or hawks. Clark believes (in. litt.) that this display has little if any significance in courtship, owing to its infrequent and unpredictable occurrence. D. Blaker and W. R. Siegfried (in. litt.) also report that typical Sousing rarely occurs in the Maccoa, at least by comparison with the species' characteristic "Vibrating Trumpet" (Clark 1964: 265) display. Although it is difficult to believe that such a complex male display as Sousing could have no sexual significance, there can be little doubt that it is subordinate to the Vibrating Trumpet call and posture as a primary courtship display in Maccoa Ducks.

It has already been pointed out (Johnsgard 1967) that the Vibrating Trumpet posture appears to be homologous with the posture and call performed by American Ruddy Ducks and White-headed Ducks at the end of their Bubbling sequence. If this is correct, the Maccoa shares at least one feature with each of the two major Oxyura groups, and as such might provide a useful "link" for determining display homologies among these seemingly behaviourally disparate forms. It therefore seems especially important to relate the Maccoa Duck's display repertoire to those of the other Oxyura species as now understood, in hopes of finding evidence concerning both the evolution of their truly remarkable display repertoires and possibly to clarify the probable taxonomic relationships of the Oxyura species.

\section{MALE BEHAVIOUR PATTERNS}

The male displays of the Maccoa Duck, although described by Clark (1964) in considerable detail, have not yet been illustrated or compared with those of other stiff-tails. From cine films provided by Clark and Siegfried it has been possible to compare critically the species' postures with those of $O$. *Contribution (No. 000) from the Department of Zoology and Physiology, University of Nebraska, Lincoln,
Nabraska. 
atstralis and $O$. jamaicensis, and to make some drawings of some of them. These displays will be discussed in the same sequence that Clark used.

1. Swimming low and swiftly in the water (Fig. 1a) is performed in a manner very similar to the aggressive approach used by most other stiff-tails. In the Maccoa, however, females are sometimes also approached in this manner, which is quite distinct from the surfboard-like approach of male Ruddy Ducks toward females. As the bird increases its speed (Fig. 1g) it assumes a posture closely resembling the "Motor-boating" rush of the Australian Blue-bill. Until there is evidence to the contrary, it seems desirable to regard all these aquatic rushes (other than the aggressive Hunched Rush towards other males) as variants of a single Rush display that is primarily oriented towards females.

2. The Vibrating Trumpet display may begin from a normal neck-erect posture, but is often preceded by a rapid upward and backward movement of the head as the bill is slightly opened and tilted downward (Fig. 1b). Within ten feet or so it may be noted that the male utters a weak whistling note at about this time (observation of W. R. Siegfried), presumably by drawing air inward as the neck is inflated. In some instances the preliminary movement of the head is rudimentary and somewhat similar to that performed during Neck-jerking (Johnsgard 1965: 326) by the Argentine Ruddy Duck, but in its extreme form (as when the male is near a female) it distinctly resembles the Dab-preening (Johnsgard 1966: 106) of the male Blue-billed Duck. The neck is then extended forward to an angle of about 40-50 degrees above the water and the tail is variably raised (45-90 degrees) as the call is uttered (Fig. 1c). The tail is not actually widely spread, but the central feathers are cocked more than the lateral ones, and they thus become somewhat separated. The nape feathers are ruffled and the back of the neck is apparently inflated. As the call is terminated the tail is lowered and a normal swimming posture is again assumed (Fig. 1d). From the initial upward head movement to the resumption of a normal swimming posture slightly over three seconds usually elapse.

3. Bill-dipping and lateral flicking of water with the bill may be performed by males independently of other displays (Fig. 1e), but usually precede or follow the Vibrating Trumpet display when performed near a female. These dipping and shaking movements, which may be best regarded as a single display, constitute precopulatory signals in the North American Ruddy Duck and possibly also have this function in the Argentine Ruddy, but in the Australian Blue-bill they have only been observed during the terminal phase of the Sousing sequence. It would seem that in the Maccoa Duck these movements have a more generalized display function than in the other species heretofore studied, but they may also occur in precopulatory situations.

4. Simultaneous diving by paired birds is regarded by Clark as a definite display. Siegfried has informed me that this is an accurate interpretation, and that the male also commonly dives, swims towards a female, and surfaces near her, whereupon he utters the Vibrating Trumpet call. The female usually responds by diving, and such sequences may continue for considerable periods. Somewhat similar mutual diving behaviour that possibly represents display activity has also been reported for the Australian Blue-billed Duck.

5. Little new information on copulatory behaviour beyond that provided by Clark is available. Siegfried (in litt.) noted that, in a precopulatory sequence which he observed, the male performed billdipping and water-flicking, while the female simply "bobbed" her head.

6. The head-pumping and tail-cocking occurring prior to diving by the Maccoa is exactly like that which occurs in the Australian Blue-billed Duck. This posturing has not yet been noted in the other stiff-tails but might well occur, since the movements do not appear to represent ritualized sexual displays inasmuch as they are not restricted by age or sex.

7. As noted, Clark described a complex display sequence which is exactly like Sousing in the Australian species, but which appears to be of subordinated importance in the display repertoire of the Maccoa. In a cine sequence which Clark kindly provided, a remarkable secene occurs that contains apparent elements of both Sousing and the Vibrating Trumpet. In this sequence a male rapidly approaches (Fig. 1h), vigorously shakes (Fig. 1g), skids to a stop beside her, performs a strong upward neck-jerk is immediately followed by his wings, and then performs a second neck-jerk identical to the first. This his opened bill anowed by a Vibrating Trumpet call that terminates with the male submerging most of (Fig. 1i). This posture, atthing backward parallel to the female in a tail-cocked posture for about two feet similar in form to it. The male lacking the convulsive movements characteristic of Sousing, is extremely movements (Fig. le) as he swims away from this tail and performs seven bill-dipping and water-flicking 
some 14 seconds elapse, during which the female shows no overt response, but only performs preening and cheek-rubbing movements. Clark has assured me that Sousing normally takes a form like that described in Ostrich, and that this is within the range of variation seen in the Vibrating Trumpet display.

8. The "hurried flight" described by Clark is identical to the Ringing Rush of Ruddy Ducks and Bluebilled Ducks. In a cine sequence provided by Clark such a flight (Fig. 1f) ends in a series of vigorous bathing movements that are terminated by wing-flapping. Wing-flapping and head-rolling movements are clearly male displays in the Australian Blue-bill Duck, and these or other comfort movements may have display significance in Maccoa Ducks. Thus, the shaking or quivering wing movements noted in the paragraph above (and which have also been observed in Argentine Ruddy Ducks) as well as general shaking movements that occasionally occur may also represent actual displays.

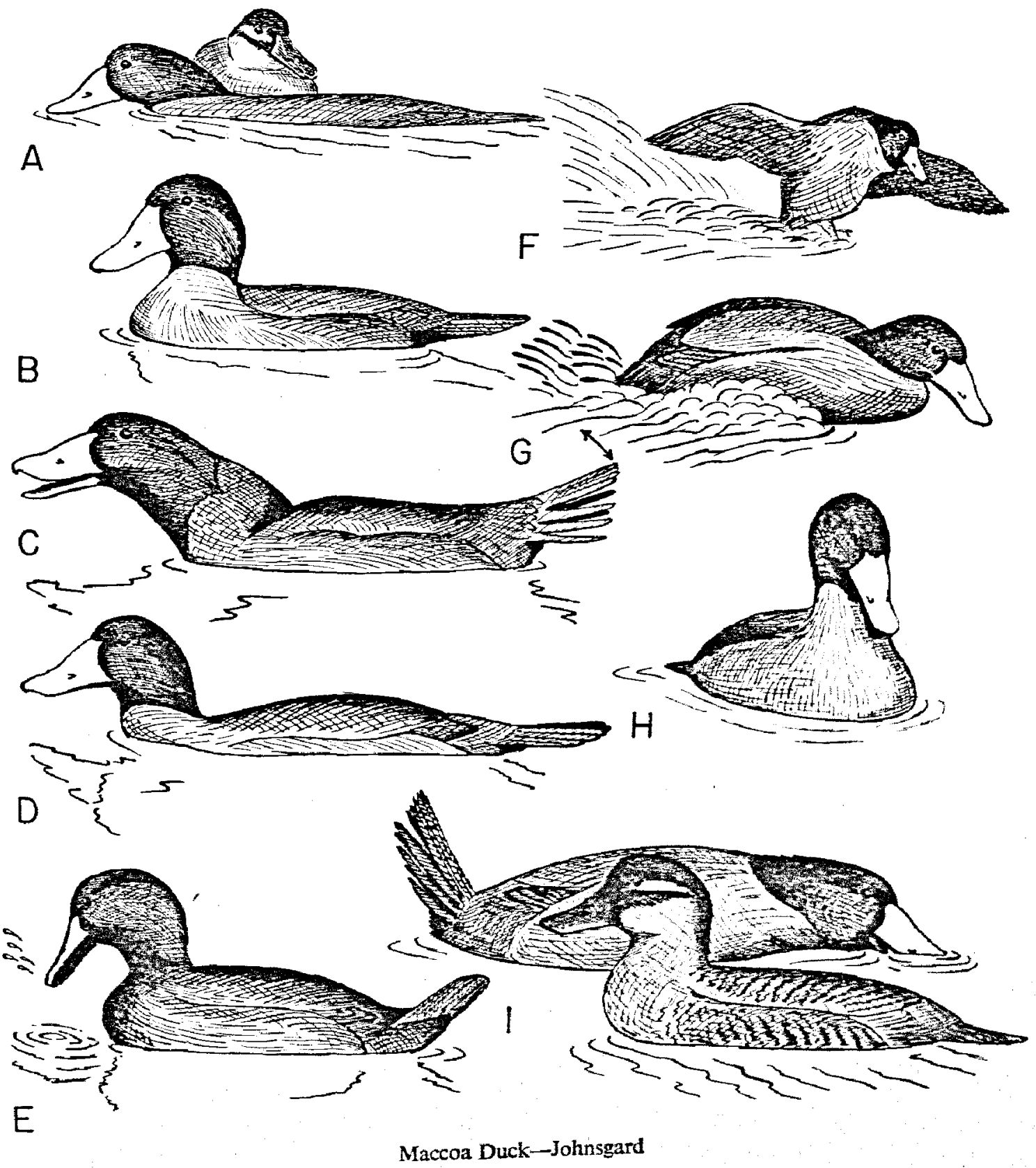




\section{DISCUSSION}

The most interesting aspect of Maccoa displays are the ways by which they vary from those of the other Oxyura species. No other Oxyura species except possibly the Masked Duck $O$. dominica are known to have loud male vocalizations that play an important role in territoriality and sexual display, although the Musk Duck Biziura lobata and Black-headed Duck Heteronetta atricapilla resemble the Maccoa in having vocalizations associated with one of their major sexual displays. If the Masked Duck proves to be similar in this regard (as now seems to be the case), it is probable that this can be considered the generalized stiff-tail situation, and the splashing or other forms of sound production are more specialized and represent derived conditions.

The Vibrating Trumpet posture is, as suggested earlier, clearly homologous with the last phase of the Ruddy Duck 's Bubbling display, although the latter's associated call is very weak. A more interesting new observation is the fact that the male Maccoa often performs one or two neck-jerking movements prior to extending its neck (see 7 above), which might well represent the motor basis for the breast-tapping elements of the Ruddy Duck's Bubbling display. Secondly, the occasional transformation of the Vibrating Trumpet display into a posture approaching Sousing presents the equally interesting possibility that the latter may have evolved as the vocal aspects of the Vibrating Trumpet were replaced by the splashing sounds associated with convulsive rocking movements of the body while the male held its head stiffly forward and the bill was submerged. Finally, the highly ritualized Dab-preening of the Australian Bluebilled Duck may be a misnomer; the similarities between this movement and the extreme form of neckjerking exhibited by the Maccoa Duck may be indicative of homologies between these displays elements and possibly also with the neck-jerking display of the Argentine Ruddy. Perhaps additional observations on both these species will help to clarify this point.

In any case, it would appear that the Maccoa Duck does exhibit real behavioural affinities with both of the other southern hemisphere Oxyura species, in addition to having a few display elements in common with the northern hemisphere forms, and as such can provide important clues regarding the probable evolution of male displays among stiff-tails.

\section{ACKNOWLEDGMENTS}

I would like to express my sincere thanks to A. Clark and W. R. Siegfried for the use of cine films and also for their very helpful comments and observations on Maccoas. In addition, D. Blaker also provided me with considerable material on Maccoa displays, for which $I$ am most grateful.

COACHER, H. VON 1952, Gänse-und Entenvögel aus aller Welt. Die Neue Brehm-Bücherei, Heft 73.

Clark, A. 1964. The Maccoa Duck (Oxyura maccoa (Eyton)). Ostrich 35: 264-276.

Delacour, J. 1959. The Waterfowl of the World. Vol. 3. Country Life, London. 270 pp.

DELACOUR, J. \& E. MAYR. 1945. The family Anatidae. Wilson Bull. 57: 1-55.

JOHNSGARD, P. A. 1961. The taxonomy of the Anatidae-A behavioural analysis. Ibis 103a: 71-85. 1965. Handboak of Waterfowl Behaviour. Cornell University Press, Ithaca, N.Y. 378 pp.

1966. Behaviour of the Australian Musk Duck and Blue-billed Duck. Auk 83: 98-110.

tailed ducks. Wildfons on the behaviour and relationship of the White-backed Duck and the stifftailed ducks. Wildfowt Trust Annual Report 18:98-107. 